\title{
Sustainable genomic research for food security in sub-Saharan Africa
}

\author{
Sethlina Naa Dodua Aryee ${ }^{1 *}$ (D), Dennis Owusu-Adjei ${ }^{2}$, Richard Osei-Amponsah², Benjamin Skinner ${ }^{3}$, \\ Emmanuel Sowatey ${ }^{4}$ and Carole Anne Sargent ${ }^{1}$
}

\begin{abstract}
Although traditional selective breeding has had a tremendous impact on both livestock and crop production in Africa, this has not kept pace with the high demand for animal and plant products on account of increasing urbanization, improved livelihoods and a rapidly growing human population. These challenges justify the need for more innovative and sustainable ways of improving animal and crop production to meet this demand. Over the last two decades the potential of genomics as a key tool to achieve improvement in desirable phenotypic traits has revolutionized the field of applied animal and plant biology. However, well informed use of such techniques has yet to be fully exploited within the context of local resources and capacity-building. The objective of this review is to highlight the rich agricultural biodiversity of sub-Saharan Africa, the potential of genomics in their sustainable use for food security, the challenges of genomic research and the strategies that can be adopted to overcome them in the implementation of agricultural genomic research in Africa. The lack of state-of-the-art laboratory research facilities, skilled human resources, poor funding and non-availability of scientific research resources, paucity of collaborative links between African researchers and a lack of engagement between key stakeholders in the agricultural value chain were identified as major barriers that affect agricultural genomic research in Africa. Finally, the recommended strategies to overcome these challenges will guide policy-makers, researchers, development partners and key stakeholders in the smooth advancement of sustainable agricultural genomic research for improved food security in Africa.
\end{abstract}

Keywords: Agricultural biodiversity, Genetic resources, Collaborations, Capacity-building, Policy

\section{Background}

Food is one of the basic needs and (arguably) rights of humanity. Unfortunately, ensuring that this basic need is met remains one of the greatest challenges faced by the global community. While some developed countries have more than enough, others, especially in developing and low-income countries, are faced with food deficit. Such deficits are not only observed in the impacts of stunting and wasting on the under-five, but include iron deficiency anaemia in girls and women, inadequacy in food consumed per household $[16,17]$, volatility in price of domestic food per country, variability in food production

\footnotetext{
*Correspondence: snda2@cam.ac.uk; aryeesethlina5@gmail.com ${ }^{1}$ Department of Pathology, University of Cambridge, Cambridge, UK Full list of author information is available at the end of the article
}

per country [69] and lifelong morbidity and mortality outcomes, such as an increased risk for cardiovascular disease (see annual Global Nutrition Reports at https:// globalnutritionreport.org/). Apart from its devastating effect on health, food insecurity has grave socioeconomic and political consequences. Hendrix and Brinkman [41] posit that by the very reason that food insecurity may contribute to inter communal tension and violent conflicts also means that 'improving food security can reduce tensions and contribute to more stable environments. Besides, food insecurity has been identified as a main factor that 'predisposes individuals to risky sexual practices' and the perpetration of sexual and domestic abuse [50]. In sub-Saharan Africa in particular or alone (and indeed elsewhere) Berazneva and Lee [11] reckon that, there were not less than 14 food riots between 2007 and 2008 .

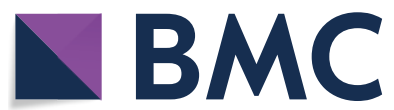

(c) The Author(s) 2021. This article is licensed under a Creative Commons Attribution 4.0 International License, which permits use, sharing, adaptation, distribution and reproduction in any medium or format, as long as you give appropriate credit to the original author(s) and the source, provide a link to the Creative Commons licence, and indicate if changes were made. The images or other third party material in this article are included in the article's Creative Commons licence, unless indicated otherwise in a credit line to the material. If material is not included in the article's Creative Commons licence and your intended use is not permitted by statutory regulation or exceeds the permitted use, you will need to obtain permission directly from the copyright holder. To view a copy of this licence, visit http://creativeco mmons.org/licenses/by/4.0/. The Creative Commons Public Domain Dedication waiver (http://creativecommons.org/publicdomain/ zero/1.0/) applies to the data made available in this article, unless otherwise stated in a credit line to the data. 
Sasson [70] also details some of these riots in Africa, but like many human endeavours, establishing casual relationships are very complicated and the same holds true for understanding the food (in) security and conflict nexus. These examples underscore the importance of food security towards, for example, health, democratic governance and development. Thus, addressing issues of food security is not only a health concern (soft security), but it is also connected to and at the same time has farreaching and broader implications for democratic consolidation and development.

In 2010, it was estimated that about 230 million people living in sub-Saharan Africa and 530 million people in Asia were suffering from extreme hunger (Roser and Ritchie [66]). Two years later, the Food and Agricultural Organization (FAO) of the United Nations stated that the primary goal of the Millennium Development Goals (MDGs) was ending extreme hunger and poverty globally by 2015 . However, this goal is still largely a mirage as reflected in the continuous food shortages and scarcity in most developing countries, including those in Africa.

In 2015, at the United Nations General Assembly, 17 global Sustainable Development Goals (SDGs) were stated with goals 2, 3 and 12 focusing on ensuring food security by 2030 (UN, [78]). Attaining these SDGs for the good of humankind by 2030 means that agricultural research for increased efficient production needs to be intensified using all the tools available and in a sustainable manner. Indeed, sustainable food productions for improved nutrition and promotion of life-long health is one of the five SDGs selected in the 2017 Global Nutrition Report, entitled "Nourishing the SDGs" (https:// globalnutritionreport.org/reports/2017-global-nutritionreport/). A striking observation made by Hendrix and Brikman [41] thus:

"Since the end of the Cold War, the world has seen
a steady decline in the number of active armed con-
flicts. However, 2011 deviated significantly from
that trend, seeing the largest year-to-year increase
in both the number of active conflicts and conflict
severity. That this increase has closely followed
spikes in international food prices-in late 2010 and
early 2011-has once again raised the question of
whether food insecurity is a cause of violent conflict."

Despite the great challenge faced by Africa due to the significant contributions of political, economic, developmental and social constraints, the continuous efforts by agricultural researchers, farmers and industry have led to the intensification of food production in recent years to address the growing demand for food in Africa (Sanchez [68], FAO [31]). Additionally, development, social and political experts believe that there is much potential in the Africa food production sector that remains untapped [61]. No wonder, there have been several theories in recent times to explain why African countries-despite being endowed with rich agricultural biodiversity (both plant and animal genetic resources)-remain net importers of plant and animal products (Omamo et al. [55], Diao et al. [20], FAO [29]. As of 2017, the overall cost of food and meat import into Africa (82 billion dollars) is staggering (FAOSTAT [32]), and may be as a result of less utilization of current innovative technologies to optimize the use of plant and animal genetic resources (Tamminen [75]). Generally, researchers all over the world are enthusiastic that Africa's use of current genomic technologies in agriculture has the potential to bridge its food insecurity gap [35]. Nonetheless, despite the enthusiasm towards the application of genomics in agriculture, the understanding and appreciation of genomics and genomic technologies is still limited. This is evident in the number of researchers and scientific conferences and meetings organized on genomics in Africa, especially towards ensuring food security. Policy-makers also maintain that adequate precautions should be taken before the implementation of genomics in food production (NASEM [53], Nature Genetics [38]). In this review, we discuss the challenges of genomic research as a tool for improved agricultural production in Africa and strategies by which they may be overcome. The preceding sections discusses the state of agricultural biodiversity in Africa highlighting some of the key challenges inherent in the sector's approach. Subsequently, we review the prospects of genomics for improved agricultural productivity and make recommendations to secure the future of Africa's agriculture.

\section{State of agricultural biodiversity in Africa}

Agricultural biodiversity refers to all genetic diversities which contributes to agricultural production (UNFAO [27]). Plant genetic resources, animal genetic resources and the crop, soil and animal microbiome are a significant constituent of the agricultural biodiversity (FAO [48]), offering, among other things, tangible benefits such as food, medicine, clothing and shelter, plus intangible benefits such as employment. Over the next few decades, it has been predicted that the majority of the world's population growth will take place in Africa with an expected increase of $26 \%$ by 2050 , thus a projected addition of about 1.2 billion people (UN [79]). Feeding a billion people in Africa requires not simply an increase in crop and animal production but also that both are achieved in a sustainable way. Unfortunately, although Africa is undoubtedly rich with many of the world's animal and plant genetic resources, these plant and animal genetic resources have not been sufficiently characterized (ILRI 
[44]). Apart from making it difficult to distinguish distinct populations from each other, the exploitation and utilization of these genetic resources becomes problematic in the absence of more extensive genome level analysis. Indigenous plant and animal genetic resources have been reported as demonstrating genetic traits such as disease and pest resistance, or drought and stress resistance, which are rarer in commercialized strains or animal breeds but important for crop and animal improvements on the continent (ILR1 [44]). Thus, the first step in meeting production targets requires that these indigenous agricultural biodiversities are fully characterized.

\section{Plant genetic resources}

The popular plant genetic resources of Africa include cassava (Manihot esculenta), yam (Dioscorea alata), cowpea (Vigna unguiculata), beans (Phaseolus vulgaris), plantain (Musa paradisiaca), banana (Musa spp), sweet potato (Ipomoea batatas), sorghum (Sorghum bicolor), maize (Zea mays) and rice (Oryza sativa). Of these plant genetic resources, cassava is the most widely cultivated in Africa (FAO 2019) and has over the years received much attention from the global community due to its potential in ensuring food security [52]. Its genetic improvement

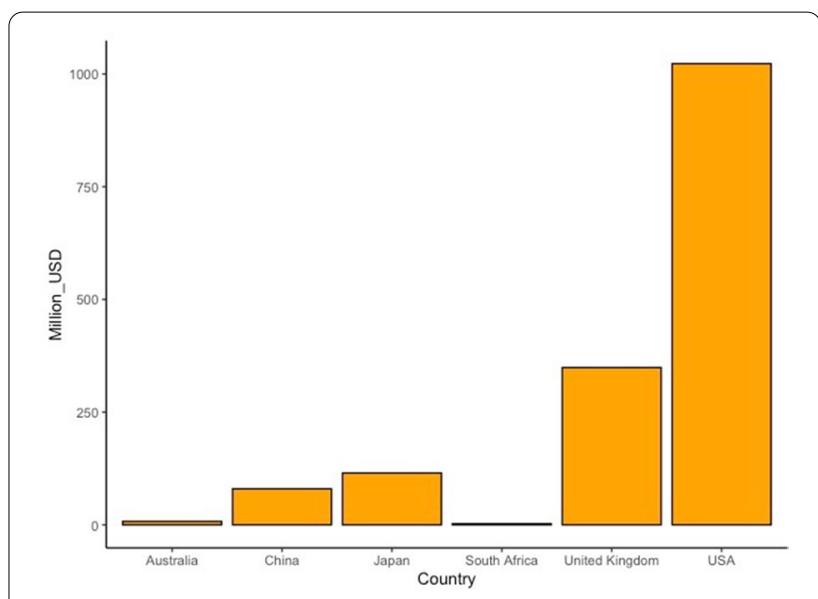

Fig. 2 Global genomic research funding for the year 2006 (Pohlhaus and Cook-Deegan [20]

has been based on selective breeding, mainly by the International Institute of Tropical Agriculture (IITA) and its associates, in over 20 African countries [62]. The world cassava production stands at 291 million tonnes, Nigeria being the largest producer with about 59 million tonnes (Fig. 1) as at 2018 (FAO 2019). According to FAOSTAT, cassava yield in sub-Saharan Africa has increased substantially, by $51 \%$ since the 1960 s, through

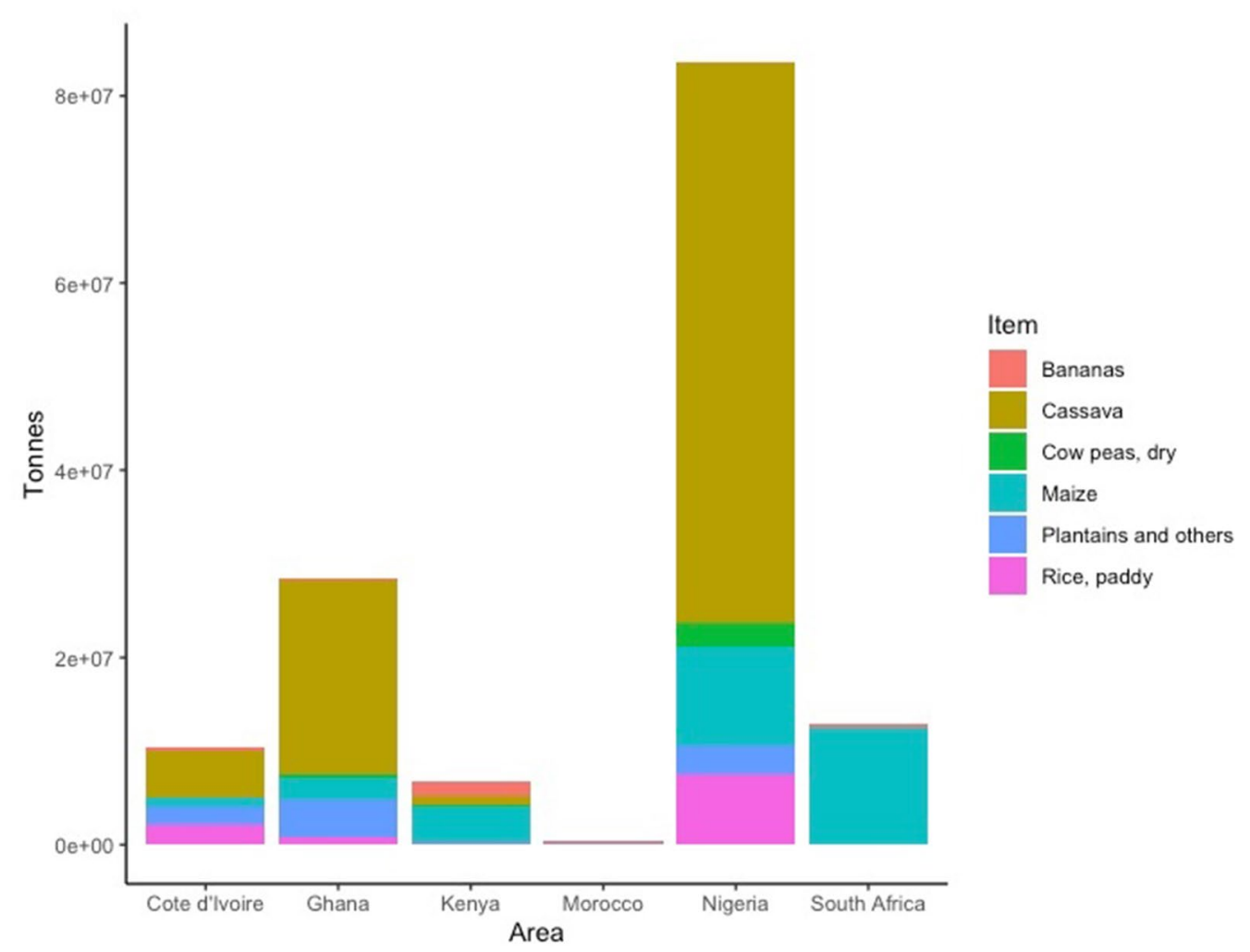

Fig. 1 Production quantity of some plant genetic resources in Africa ([32] source FAOSTAT 
selective breeding, indicating the huge potential of genetic improvements in Cassava which were untapped (Ortiz and Hartmann [57]) (Fig. 2).

The maize crop is another staple widely consumed in Africa that has received much attention from the global community due to its utilization worldwide in both human and animal foodstuffs. In the bid to improve maize yield, IITA and its partners have worked in eleven countries in West and Central Africa since the 1970s. As a result, they have released 267 maize cultivars including various high yielding varieties; these cultivars raised maize yield from 1.6 million tonnes/year to 2.5 million tonnes/year (Ortiz and Hartmann [57]). The International Maize and Wheat Improvement Centre (CIMMYT) has also been involved in breeding to prevent low yielding in maize crops due to drought. Countries like South Africa and Zimbabwe have benefitted from these new cultivars which continue to spread to the other parts of Africa [7]. Maize farmers in Africa now produce 25\% of the world's consumption level using cultivars developed through traditional breeding methods (Byerlee et al, [15], [26], a role ascribed as critical in preventing regular maize shortages.

Demand for rice keeps increasing, especially in West Africa due to population increase and an upsurge in taste for rice dishes. This has motivated governments to give special attention to its production (FAOSTAT [33]). Major challenges to commercial rice cultivation, especially in sub-Saharan Africa, include drought, flood, rice yellow mottle virus infection (RYMV) and blast [6]. In the 1960s the rice cultivars introduced to Africa were those originally developed alongside irrigation technologies in Asia. These adapted quite well until the development of a locally bred rice known as the new rice for Africa, shortened as the NERICA, was reported to be more resistant to drought and have a better yield compared to the Asian rice cultivars [23]. Genetic characterization of 18 rainfed upland NERICA varieties revealed a massive potential in the genetic improvements as 131 quantitative trait loci between SSR (simple sequence repeats) markers associated with 11 agronomic traits were recorded in this rice variety [34].

Plantains and bananas are other major staples produced and consumed locally. Yield exceeds 31 million $\mathrm{t} /$ year, usually cultivated by small scale farmers and family farms, and accounts for one-third of the world's production (FAOSTAT [32]. Major research initiatives to increase production were centred around the promotion of banana and plantain crops for the export market. Yield improvements were achieved through selective breeding and were masterminded by the International Association for Research on Plantain and other Cooking Bananas (IARPCB), with additional breeding initiatives undertaken by the Centre African de Recherches sur Bananiers et Plantains (CARBAP) in Cameroon, by the International Institute of Tropical Agriculture at Onne in Nigeria, Côte d'Ivoire, and Uganda, and the Crop Research Institute of the Council for Scientific and Industrial Research (CRI-CSIR) in Ghana (Lescot and Ganry [48]).

Cowpea is one typical plant protein source that was first discovered and domesticated in Africa, more precisely Ethiopia. It was later spread throughout the world but thrives very well in the Savannah (an agro-ecological zone characterized by a mixture of grasslands and woodlands) [46]. Cowpea remains an important crop in Western and Central Africa because of its great economic impact on the livelihoods of people, and a cultural preference over the soya bean due to the variety of meals that can be made from it (Lambot [45]). Production has recently received much research attention, especially in Ghana, where The Crop Research Institute (CRI-CSIR) released five new cowpea cultivars specifically developed to improve their resistance to pests and diseases. In addition to the improvement through traditional breeding methods, there has also been an interest in genetically improved cowpea (genetically modified cowpea), which is currently at a trial stage. However, if a GM crop is passed by the National Biosafety Authority, this improved cowpea can add about GHC 38 million annually to the cowpea production, currently at around GHC 415 million (Gakpo and Quainoo [36]).

\section{Animal genetic resources}

Africa is home to a rich variety of animal genetic resources which have been relatively underexploited in the past but could contribute greatly to ensure food security and wealth creation on the continent (FAO [30], ILR1 [44]). These animal genetic resources mostly include livestock species such as poultry (chickenGallus domesticus, duck-Anas platyrhynchos, turkeyMeleagris gallapavo, quail-Coturnix japonica, guinea fowl-Numida meleagris, ostrich-Struthio camelus), the greater cane rat, or grasscutter (Thryonomys swinderianus), cattle (Bos taurus), sheep (Ovis aries), goats (Capra aegagrus hircus), and pigs (Sus scrofa).

It has been reported that about $70 \%$ or 150 million of the rural poor in sub-Saharan Africa are at least partially dependent on livestock to sustain their livelihoods with most being pastoralists (LID [49], Otte and Knips [60], AU-IBAR [4]. Correspondingly, sub-Saharan Africa has more long-term grazing fields compared to any other continent in the world (Ritchie and Max [65], with livestock production contributing around $35 \%$ of the agricultural GDP (Ehui et al. [24]). The production of eggs, pork and poultry meat in sub-Saharan Africa tripled between 1970 and 2000 through selective breeding and improved livestock nutrition. Milk, 
mutton and goat meat production doubled and that of beef increased by nearly 70\% (FAOSTAT [32]). Nonetheless, production has not kept pace with the growing population (1.2 billion people at a $2.3 \%$ rate of increase per year) (UN [4]), and this has contributed to subSaharan African countries being net importers of livestock and livestock products. There is therefore the need to bridge the widening gap between supply and demand of animals and their products. One solution is to maximize livestock production through animal genetic improvements and the organization of sustainable breeding programmes for livestock species on the continent (FAO [48]). Undoubtedly, such improvements bring added benefits that counteract poverty in Africa, as jobs will be created, food will be supplied, income will be generated and protein deficiency gaps in most sub-Saharan African countries could be bridged (Sachs et al. [67]).

Apart from the role livestock farming plays in the lives of the rural poor, interestingly, it is becoming critical to the survival of the urban poor as well; the urban poor have engaged in livestock farming as a result of rising unemployment in sub-Saharan Africa. Even though animal husbandry is usually not the main occupation of urban households, it often has an important role for income generation and diet supplementation (FAO [57]).

\section{Microbiome}

The genetic material of all microbes (viruses, fungi, protozoa and bacteria) is referred to as the microbiome. Exploiting the agricultural microbiome has been suggested as one of the promising solutions to achieving food security, food safety and a healthy environment. (Singh and Trivedi [71]. Harnessing microorganisms found in crop species and in the soil are essential in promoting agricultural productivity to ensure food security. These microorganisms have been reported to complement plant, soil and animal health. The global realization of the importance of the microbiome in promoting agricultural productivity, health and the environment has generated lots of support through public and private investments, especially in developed nations. Also, as food production increases, the complexities involving food storage, distribution and authentication of wholesome food cannot be downplayed. Making sure that food is safe for consumption has led to the implementation of food safety regulations worldwide. However, in most developing countries issues related to food insecurity, ineffective health systems, political volatility, and natural disasters are given much attention by the government and the media, whereas food safety is often given little attention despite its critical impact on the above (FAO
[28], Singh et al. [72]). An important strategy in this direction could be to use novel genomic technologies to complement traditional farming techniques to increase food production while ensuring its safety in sub-Saharan Africa.

\section{Prospects of genomics for improved agricultural productivity in Africa}

Genetic improvements in both crop and livestock species are dependent on the selection of naturally occurring genetic variants that exist within the population as a whole. How these genetic variations are exploited is key. The two main options are traditional breeding methods, using the observed phenotypic traits to select breeding stock for the next generation, and the use of improved genomic technologies. The application of genomic tools-an aspect of molecular biology where genomic information is manipulated and analysed-in the improvement of agricultural productivity for ensuring food security and safety is known as agricultural genomics [82]. Known genomic technologies include high throughput genotyping, sequencing, gene expression profiling, recombinant DNA technologies, genome wide association studies and genotypic selection (including marker assisted selection, [25].

In the past, plant and animal genetic improvements geared towards increasing food production in Africa have been based on traditional genetic improvement methods including Quantitative Trait Loci (QTL) identification. These techniques involve the use of phenotypic and pedigree information to obtain the breeding values for selection purposes during breed improvement. However useful this has been in the past, it is often cumbersome, time consuming, inefficient and sometimes inexact [22]

The advent of genomic technologies such as the molecular marker assisted selection has been reported to be quite efficient in increasing productivity, especially in developed countries [21]. Agricultural production in Africa is faced with (different) challenges including drought, disease and heat stress resulting in low agricultural yield. Nonetheless, genomic selection has been proven by Cerrudo et al. [18] to increase genetic gain for heat and drought tolerance from 4.4 to $19.4 \%$ in maize. This shows that the production of a crop which serves as a major carbohydrate component of the food consumed by both humans and animals in Africa can be increased drastically through genomic marker assisted selection to meet the growing demand.

Recent resequencing of four whole genomes of upland NERICA rice revealed possible causal genes associated with agronomic traits such as tolerance to salinity, bacterial leaf blight susceptibility, grain shattering and awnness. This shows the huge potential of the application of 
genomics in the improvement of plant cultivars developed through traditional selective breeding.

Implementation and adoption of genomic technologies for improved agricultural production in Africa should be viable on account of the advancement of the technology. Mistakes and failures from such research should offer ground-breaking solutions to genomic challenges that could be faced in the implementation and sustainability of genomics on the continent. For instance, QTL studies have been proven in the past by researchers in developed countries to be difficult to translate in the field, especially when dealing with economic complex traits as these are normally affected by interactions between several genes [39]. This information can help researchers overcome possible challenges that may manifest when working with such traits. For example, Garner et al. [37] demonstrated that selection for heat tolerant cattle in Australia based on genomic breeding values also had a positive effect on milk production. Such dual phenotypic outcome indicates that either some of the alleles have pleiotropic effects, with an impact on both traits, or that alleles in linkage disequilibrium are co-inherited but influence each trait independently. Without detailed genomic analysis, selection on breeding values and scorable traits is less precise than breeding based on marker alleles with known genetic contributions to specific phenotypes. In this vein, if the same approach were applied to indigenous African cattle species, there is no guarantee that producing heat tolerant cattle will improve milk yield if the alleles are either different in these local populations or consist of alternative haplotypes of allelic combinations between co-inherited loci.

In ensuring food security and food safety in Africa, the application of genomic technologies in food and the agriculture microbiome cannot be downplayed. The application of genomics in the microbiome of food has been used successfully to address some agronomic challenges and the challenges associated with food safety in developed countries. For example, the Food and Drug Administration (FDA), the Centre for Disease Control and Prevention, United States Department of Agriculture (USDA), the European Food safety authority (EFSA) The African Collaborative Centre for Microbiome and Genomics Research (ACCME) are relying on genomic technologies such as whole genomic sequencing in the detection of pathogens in food, in and outside of the human body [3], Beck et al. [9]. The initiation of the $100 \mathrm{~K}$ pathogen genome project has made it possible to study the diversity of bacteria genome which is crucial in the investigation of disease-causing bacteria found in foodstuffs, bacteria likely to cause disease outbreaks and other microbiome studies directly related to agricultural productivity [83]. In that vein, sub-Saharan Africa while ensuring that food is secured can employ genomic technologies to ascertain the quality and safety of food consumed.

\section{Limitations, and strategies to overcoming limitations, of genomic research in Africa} Resources and funding

Funding for genomic research in most developed countries was initiated by governments and non-profit nongovernmental organizations but was later complemented for improved livelihoods (including health, medicine and agriculture) by private research and development (R\&D) funding (Pohlhaus and Cook-Deegan [63]). A major hindrance to the implementation and application of agricultural genomic research in Africa is the lack of resources (human and institutional capacities) and funding. As at 2006, the USA funded about one-third of the world's genomic research (1 Billion US dollars), South Africa funded about $\$ 2$ million worth genomic research (Fig. 1), whereas there was no report on funding for genomic research in sub-Saharan Africa (Burke and de Francisco [14], Pohlhaus and Cook-Deegan [20]).

Although researchers in Africa are optimistic about the impact genomics could have on agricultural research, its cost, and delayed or inadequate funding remain a huge challenge. For instance, the cost of genotyping and sequencing platforms ranges between $\$ 80,000$ and $\$ 700,000$ [43]. These costs exclude infrastructure, staff payments, reagents, power supply and laboratory equipment. Also, funding from most governments in Africa towards scientific research is a relatively low priority. Furthermore, research funds from foreign donors are often delayed due to complicated regulatory and policy issues. These delays contribute to tardiness in the progress of scientific research geared towards agricultural improvements. Funding gaps and funding challenges could be bridged through public-private and donor partnerships with proper maintenance and supervision (Osei-Kyei and Chan [59]). This could be beneficial to all partners involved, lessening the burdens of researchers, promoting and strengthening agricultural genomic research, improving agricultural productivity and enhancing food security in Africa.

\section{Inadequate institutional capacities}

Genomic research requires adequate institutional capacities including well-equipped laboratories. A major challenge faced by most African scientific research institutions is the lack of ultra-modern research facilities including laboratories. These laboratory facilities are relatively expensive world-wide, but importation and lengthy 
procurement issues associated with their purchase make them even more expensive in Africa than in most parts of Europe and Asia. Currently, due to the lack of adequate genomic laboratory services at a local level, researchers in Africa often transport genomic materials including tissues, DNA and RNA for genomic analysis abroad (e.g. to Europe and Asia). This is not just costly but time wasting and inefficient, as some of these genomic materials may end up degrading. Some proactive measures that could be used to eradicate this problem include engaging government, private businesses and non-governmental organizations to invest in the improvement of scientific research by stocking and refurbishing pre-existing laboratories. Governments of African countries can also help by reducing the bureaucratic hassle involved with procuring laboratory equipment [2].

\section{Human resource capacity}

Human resource is a critical asset any organization must have. Extensive resources are essential to build the capacity of human resources of all organizations including genomic research facilities [1]. In every research project, apt personnel and skills are required, and it is important to have a deliberate policy to attract, train, retrain and retain the best personnel in the field. In that regard, poorly trained, poorly motivated and inadequate research team members are disadvantageous to any agricultural genomic research project. Therefore, it is necessary to invest in the training, development and retainment of the right calibre of personnel for the sake of enhancing performance and the attainment of the research goals (Elnaga and Imran [14]). To improve agricultural productivity through genomics in Africa, research staff should be trained to understand the research goals before implementation of a research project. They should be made to understand how important their role in ensuring food safety and security is for a billion people who depend on their outputs. Principal investigators and project managers also need tailored leadership training on how to engage research staff, the community and policy-makers. Project managers should also endeavour to explain research goals, motivate and engage the team rather than just giving directives which is often the perception of its members [2].

\section{Research collaboration}

Research collaboration is a term used to describe the process where researchers from different research groups (either within an institution or outside the institution) come together to conduct research to achieve a specific research aim or objective. Over the years, collaborative research has been encouraged all around the world as it has been assumed to be 'a good thing' in advancing knowledge, especially in science and technology. To promote enthusiasm towards collaborative research in Africa, the term "collaborative research" must be understood within the contexts of individuals, groups, or institutions, since collaborative research comes in various forms. These range from offering advice to participating actively in a research project, and from sharing data to co-authoring a research paper. Such collaborations have multiple advantages which include personal and institutional capacity-building through shared knowledge and infrastructure (Katz and Martin 1997; Nyström et al. [54], Osei-Amponsah et al. [58]).

To ensure food security is achieved in Africa, collaborative research has a crucial role. Researchers can engage with others within Africa and, or abroad [81]. According to Wagner et al. [80], international research collaborations have been accepted by most governments in the developing world and are widely used instead of other models to build their scientific research capacity. This they believe has had a significant impact on scientific research in developing countries which is evident in the number of collaborative research papers published. A study conducted by Pouris and Ho [64] to ascertain the importance of collaborative research between Africa and the international community revealed that over the period of five years from 2007 to 2011, the scientific research papers produced as a result of collaborations between Africa and the international community saw a dramatic growth by $66 \%$ whereas collaborative publications in country among African researchers only grew by $35 \%$.

Based upon research outputs, the fields that have received the most attention in Africa include the environmental sciences and ecology, agriculture, pharmacology and infectious diseases. Research areas such as genetics and heredity, biotechnology, biochemistry and molecular biology appear to have received less attention when compared to the global statistics (Fig. 3). Onyancha and Maluleka [56] suggested that those research areas with a focus on poverty alleviation and ensuring food security, which are lagging, can be improved through the organization of collaborative research programmes between African researchers and the international communities but they also feared that the dependence on international collaborations by African researchers may have a negative impact on the continent's research priorities. In that regard, pan-African research collaborations should be encouraged since the problems or challenges faced in the fight towards ensuring food security are common to most countries on the continent. Also, for win-win research collaborations between Africa and the international communities, research collaborations should not follow the usual format of north-south 


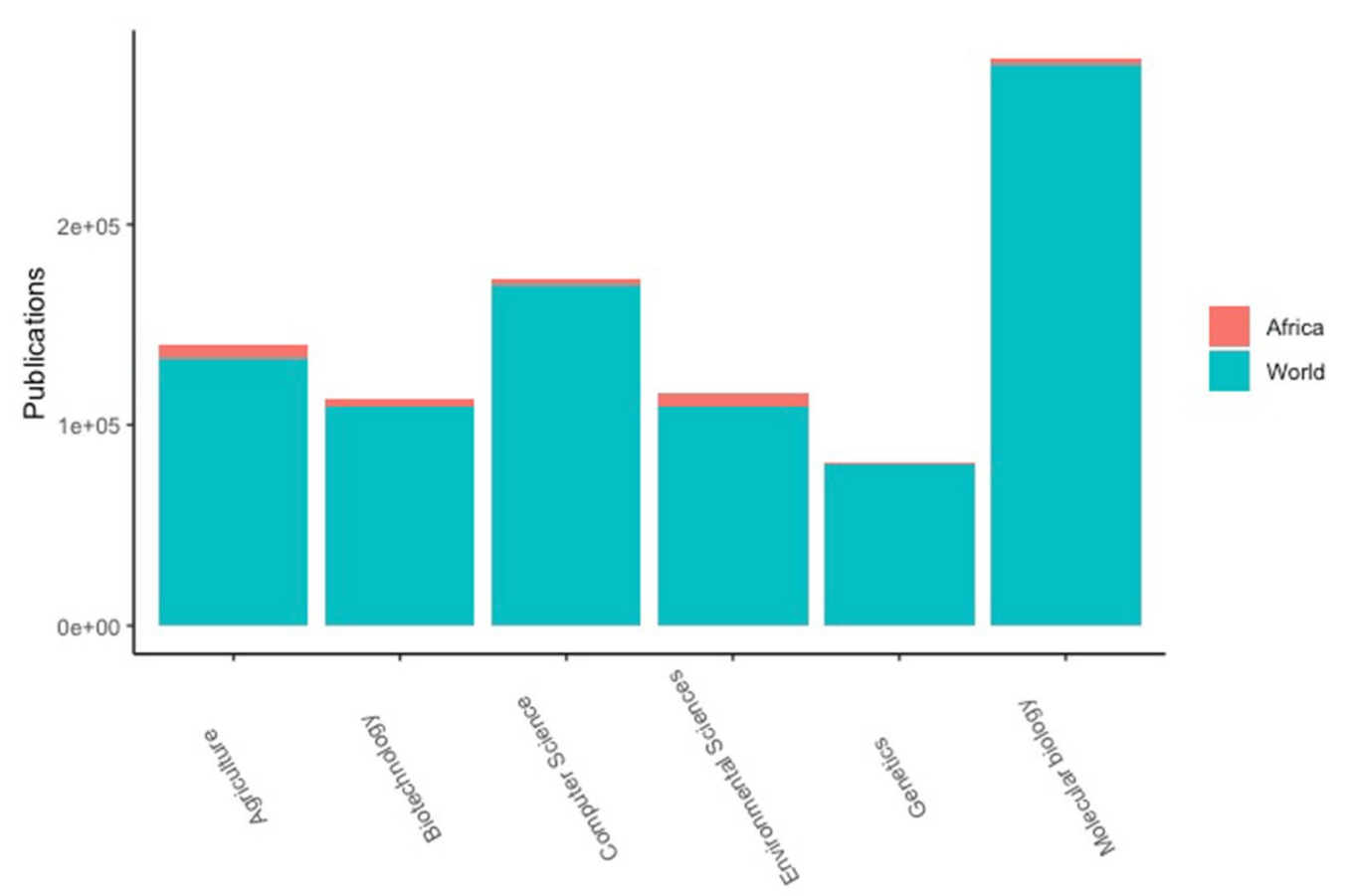

Fig. 3 Research areas and the rate of publication in Africa against the World from 2007 2011. Source: [64]

(developed-developing-countries) collaborations where the south collaborator (developing country) is only involved in assisting in the field work which mostly involves data collection. This often leads to resources of developing countries being used without an equal partnership [64]. Thus, for an equal partnership to be achieved there must be collaborative efforts on an international level just as prescribed by the Nagoya protocol which specifically covers agriculture and food security in its remit to protect local genetic biodiversity (Nagoya Protocol [76].

\section{Genomic data management, storage and sharing}

It is estimated that by 2025 genomic data could be the largest data generator on earth [74]. This means that managing genomic data is steadily gaining higher priority within project design and requires good data management and bioinformatic skills (Zhang et al. [84]. In genomic projects, data are manipulated by different people and at different locations thus making it difficult to understand the processing pathways unless accurate records are kept at each stage (Barone et al. [8]. Genomic data storage is also very important, and topics such as when, where and in what formats data are to be stored should be discussed before initiating any large-scale project. As much as keeping records in laboratory notebooks and spreadsheets are important, they may be limiting digital platforms with associated records of programs and scripts, and cloud storage are becoming more commonplace [19].

For a smooth running of agricultural genomic research, data sharing is imperative. Data sharing is regarded as an important tool for enabling, promoting and improving genomic research for public benefits [47]. This is made possible and effective by the use of accessible repositories. These include sequence databases such as the NCBI GenBank, European Nucleotide Archive (ENA), and the DNA Data Bank of Japan (DDBJ), functional annotation databases such as the Encyclopaedia of DNA Elements (ENCODE), Genome browsers for visualization and exploration (e.g. the UCSC genome browser, Ensembl and sequence variant databases such as the International Genome Sample Resource (IGSR, 1000 Genomes all of which allow effective genomic data sharing and storage among researchers internationally [73]. Unfortunately, none of these databases are hosted or mirrored in Africa which can create some delay in accessing their contents. Just as Genbank, ENA and DDBJ are able to synchronize with each other daily, it would be helpful to have an 'African Nucleotide Repository' doing the same. This would require more training of genomics researchers and promoting what is available.

Additionally, establishment of gene banks are imperative, especially in crop genomic research. Establishment 
of gene banks in sub-Saharan Africa will enable the conservation of the diverse genetic resources (plant or crop genetic materials) of crops and their wild relatives within sub-Saharan Africa protecting them from possible extinction (Benson et al. [10]. Furthermore, the recent efforts by the African Union to implement regional and continental gene banks for conservation of animal genetic resources in various regions of Africa should be encouraged and pursued (AU-IBAR [4]).

Data sharing is gradually being regulated by principles both ethical and scientific to ensure the protection of participating researchers (GEN2PHEN Knowledge Center). Intellectual property (IP) ownership, data and sample sharing terms must be stated at the initiation of the project. This is necessitous for harmonizing the interests of the researchers involved, the research project, sponsors, and sample donors $[3,77]$. Data sharing policies in various countries where studies are conducted must also be regarded [12].

Most countries in Africa are yet to develop their own important regulatory frameworks, material transfer agreements, ABS (Access and Benefit Sharing), and other regulatory policies for the exchange of genetic materials even if facilities exist in other locations for this purpose. In this regard, to ensure a great utilization of agricultural genomic data for improving food security in Africa, African researchers must be prepared to handle and manage large genomic datasets by putting the necessary structures in place. Researchers and data analysts/bioinformaticians must also receive continuous training on genomic data management, data storage and data sharing as scientific knowledge advances.

\section{Farmer and community engagement}

Despite the fact that various scientific studies indicate that food and meat produced by genetic modification is safe for human consumption, some consumers are still sceptical about the whole idea of genomics [13]. Undoubtedly, without public support for crop and animal improvements through genomic research, production of both will remain underdeveloped and this will have a negative impact on ensuring that food is readily available to meet the growing demand [51]. Researchers must therefore engage farmers and the community to achieve the smooth running of agricultural genomic research in Africa through education and outreach to the primary stakeholders. Such stakeholders include farmers, sociologists, molecular biologists, agriculturists, genomicists, biostatisticians, bioinformaticians and community opinion leaders to help facilitate this process and improve acceptance and ownership of the final product by all involved.
Ultimately, researchers must not be silent, they must engage farmers and consumers through various symposia or media engagements communicating the important role agricultural genomic research plays in improving livelihoods by making food safe. In sub-Saharan Africa, $60 \%$ of the population are small-holder farmers (Goedde et al. [40]); however, the majority have had little or no formal education [5]. Agricultural genomicists can serve as educators by providing tailored materials to farmers using pictorial diagrams and providing simple illustrations about agricultural genomic research. Pictorial materials and diagrams have the potential to cross language barriers and can be substantial in most African countries where language may be a challenge. This will go a long way to improve the agricultural literacy among farmers in Africa. Members of the general public, journalists and policy-makers can also be engaged by using social media tools and videography to provide factual information on genomics in a very creative and appreciable manner. Africa must also consciously have a policy and encourage the development and use of innovative technologies in animal agriculture. For instance, the use of videography and pictorial illustrations to provide information is believed to be a valid didactic approach to understanding and appreciating science [42]. When the public is well informed about the importance of agricultural genomic research, acceptance becomes easier and food production can be increased in a more sustainable and secure way in Africa.

\section{Conclusion}

This review sets its purpose as identifying the challenges and prospects of using agricultural genomic research as a tool for ensuring that food is secure for the growing population in sub-Saharan Africa. Beyond its health importance, food security and or insecurity holds implications way beyond the strict remit of nutritional health. Its implications are diverse, and this means matters of food (insecurity) are a vital human security endeavour. Africa has witnessed numerous forms of violent conflicts and other episodes of political and economic instability which could be a result and consequence of food insecurity.

Sub-Saharan Africa is endowed with rich agricultural biodiversity (plant and animal genetic resources) which if exploited through advanced genomic research has a huge potential in bridging the food deficit gap on the continent. Additionally, although agricultural genomic research is eminent in the acceleration of agricultural production in Africa, agricultural genomic researchers, policy-makers and key industry players must also identify potential challenges before implementation. These challenges are not limited to scientific advancement, but include an understanding of the social, economic and cultural needs of 
farmers, and better education of the stakeholders. In this context, African governments, researchers and the private sector must partner and work as a team (in terms of funding, provision of well-equipped laboratories, and other resources) towards building appropriate research capacity and routes for implementation of the outputs.

There's also the need for continuous training of scientists in data management, handling and storage as these are crucial for successful agricultural genomic research and we recommend the establishment of a host genomic database in Africa for easy data sharing among researchers. Scientists should also endeavour to build trustworthy collaborations with each other and engage the public more often through graphical illustrations in order to build up that research trust and acceptability. We have outlined how genomics may be an important tool for democratic consolidation and political stability. Thus, if food (in)security has wide consequences for any state, then the approach geared at solving it does the same. Hopefully, we will begin to see more intense engagements and collaborations between academics in seemingly unrelated fields who will work together and find creative and novel means to deal with a variety of old and new human challenges.

\begin{abstract}
Abbreviations
SDGs: Sustainable Development Goals; FAO: Food and Agricultural Organization; MDGs: Millennium Development Goals; IITA: International Institute of Tropical Agriculture; GM: Genetically modified; SSR: Simple sequence repeats; NERICA: New Rice for Africa; DNA: Deoxyribonucleic acid; RNA: Ribonucleic acid; NCBI: National Center for Biotechnology Information; ENA: European
\end{abstract} Nucleotide Archive; GDP: Gross Domestic Product.

\section{Acknowledgements}

The authors are grateful to the Schlumberger Faculty for the Future Foundation and the Cambridge Trust for awarding Sethlina a scholarship to pursue her PhD studies of which this study is part of.

\section{Author contributions}

All authors participated significantly in the drafting and revision of this article.

\section{Funding}

Not applicable.

Availability of data and materials

Not applicable.

Ethical approval and consent to participate

Not applicable.

\section{Consent for Publication}

All authors have given their consent for the publication of this study.

\section{Competing interests}

The authors have declared no competing interests.

\section{Author details}

${ }^{1}$ Department of Pathology, University of Cambridge, Cambridge, UK. ${ }^{2}$ Department of Animal Science, University of Ghana, Legon, Ghana. ${ }^{3}$ School of Life Sciences, University of Essex, Essex, UK. ${ }^{4}$ Institute of Criminology, University of Cambridge, Cambridge, UK.
Received: 28 September 2020 Accepted: 20 January 2021

Published online: 04 February 2021

\section{References}

1. Abbay A. The HRM agenda of process focused organizations, Paper presented to the national workshop of the millennium civil service. 2008; Federal Civil Service Agency, Addis Ababa, Ethiopia

2. Adebamowo SN, Francis V, Tambo E, Diallo SH, Landouré G, Nembaware V, Dareng E, Muhamed B, Odotula M, Akeredolu T, Nerima B, Ozumba PJ, Mbhele S, Ghanash A, Wachinou AP, Ngomi N. Implementation of genomics research in Africa: challenges and recommendations. Global Health Action. 2018;1 1(1):1419033. https://doi.org/10.1080/16549 716.2017.1419033.

3. Adebamowo CA, Igbe MA. Qualitative study of knowledge and attitudes to biobanking among lay persons in Nigeria. BMC Med Ethics. 2012;2012(13):27.

4. African Union-InterAfrican Bureau for Animal Resources (AU- IBAR). The State of Farm Animal Genetic Resources in Africa. AU-IBAR publications; 2019.

5. Aryee SND, Osei-Amponsah R, Adjei OD, Ahunu BK, Skinner BM, Sargent CA. Production practices of local pig farmers in Ghana. Int I Livest Prod. 2019;10(6):175-81.

6. Balasubramanian V, Sie M, Hijmans RJ, Otsuka K. Increasing rice production in sub-Saharan Africa: challenges and opportunities. Adv Agron. 2007;94:55-133.

7. Bänziger $M$, Araus J. Recent advances in breeding for drought and salinity stress tolerance. In: Jenks MA, Hasegawa PM, Jain SM, editors. Advances in molecular breeding towards drought and salt tolerance crops. Netherlands: Springer; 2007. p. 587-601.

8. Barone L, Williams J. Micklos D (2017) Unmet needs for analysing biological big data: a survey of 704 NSF principal investigators. PLoS Comput Biol. 2017;13(10):e1005755.

9. Beck KL, Haiminen N, Chambliss D, Edlund S, Kunitomi M, Huang BC, Kong N, Ganesan B, Baker R, Markwell P, Kawas B, Davis M, Prill RJ, Krishnareddy H, Seabolt E, Marlowe CH, Pierre S, Quintanar A, Parida L, Dubois G, Kaufman J, Weimer BC. Monitoring the microbiome for food safety and quality using deep shotgun sequencing. bioRxiv. 2020. https:// doi.org/10.1101/2020.05.18.102574.

10. Benson EE, Harding K, Debouck D, Dumet D, Escobar R, Mafla G, Panis B, Panta A, Tay D, Vanden Houwe I, Roux N. Refinement and standardization of storage procedures for clonal crops—Global Public Goods Phase 2: part I. Project landscape and general status of clonal crop in vitro conservation technologies. System-wide Genetic Resources Programme, Rome, Italy.

11. Berazneva J, Lee DR. Explaining the African food riots of 2007-2008: an empirical analysis. Food Policy. 2013;39:28-39.

12. Birney E, Hudson TJ, Green ED, Gunter C, Eddy S, Rogers J, Harris JR, Ehrlich SD, Apweiler R, Austin CP, Berglund L, Bobrow M, Bountra C, Brookes AJ, Cambon-Thomsen A, Carter NP, Chisholm RL, Contreras JL, Cooke RM, Crosby WL, Dewar K, Durbin R, Dyke SO, Ecker JR, El Emam K, Feuk L, Gabriel SB, Gallacher J, Gelbart WM, Granell A, et al. Prepublication data sharing. Nature. 2009;2009(461):168-70.

13. Blomstedt CK, Gleadow RM, O'Donnell N, Naur P, Jensen K, et al. A combined biochemical screen and TILLING-approach identifies mutations in Sorghum bicolor L. Moench resulting in acyanogenic forage production. Plant Biotechnol J. 2012;10:54-66.

14. Burke MA, De Francisco A. Global funding and flows (chapter 2), monitoring financial flows for health research (http://www.globalforumheal th.org/filesupld/monitoring_financial_flows2/MFF04chap2.pdf). Geneva: Global Forum for Health Research; 2004

15. Byerlee D, Anandajayasekeram P, Diallo A. Maize research in Sub-Saharan Africa: an overview of past impacts and future prospects. Mexico, DF, Mexico: CIMMYT Economics Working Paper 1994; 94-03.

16. Cafiero C, Melgar- Quiñonez HR, Ballard TJ, Kepple AW. Validity and reliability of food security measures. Ann N Y Acad Sci. 2014;1331 (1):230-48. https://doi.org/10.1111/nyas.12594.

17. Cafiero C, Viviani S, Nord M. (2018) Food security measurement in a global context: the food insecurity experience scale. Measurement. 2018;116:146-52. 
18. Cerrudo D, Cao S, Yuan Y, Martinez C, Suarez EA, Babu R, Zhang X, Trachsel $S$. Genomic selection outperforms marker assisted selection for grain yield and physiological traits in a maize doubled haploid population across water treatments. Front Plant Sci. 2018;9:366. https://doi. org/10.3389/fpls.2018.00366.

19. Dankar FK, Ptitsyn A, Dankar SK. The development of large-scale deidentified biomedical databases in the age of genomics-principles and challenges. Human Genomics. 2018;12(1):19. https://doi.org/10.1186/ s40246-018-0147-5.

20. Diao X, Fan S, Headey D, Johnson M, Nin Pratt A, Yu B. Accelerating Africa's food production in response to rising food prices: Impacts and requisite actions. Discussion Paper No. 825. International Food Policy Research Institute; 2008.

21. Dekkers JCM. Commercial application of marker- and geneassisted selection in livestock: strategies and lessons. J Anim Sci. 2004;82:E313-328E.

22. Dekkers JC. Application of genomics tools to animal breeding. Curr Genomics. 2012;13(3):207-12. https://doi.org/10.2174/138920212800543 057.

23. Dontsop P, Diagne A, Okoruwa OV, Ojehomon V, Manyong V. Estimating the actual and potential adoption rates and determinants of NERICA rice varieties in Nigeria. J Crop Improv. 2013;27(5):561-85. https://doi. org/10.1080/15427528.2013.811709.

24. Ehui S, Samuel B, Timothy W, Siet M. Food security in sub-Saharan Africa to 2020. Socioeconomics and policy research working paper 49. Nairobi, Kenya: International Livestock Research Institute (ILRI); 2002.

25. Eichler EE. Genetic variation, comparative genomics, and the diagnosis of disease. N Engl J Med. 2019;381:64-74.

26. Eriksson D, Akoroda M, Azmach G, Labuschagne M, Mahungu N, Ortiz R. Measuring the impact of plant breeding on sub-Saharan African staple crops. Outlook Agricult. 2018:47(3):163-80. https://doi.org/10.1177/00307 27018800723.

27. Food and Agriculture Organization (FAO) What is Agrobiodiversity. United Nations Food and Agriculture Organization; 1999.

28. Food and Agriculture Organization (FAO). Final report FAO/WHO regional conference on food safety for Africa. Harare, Zimbabwe, 3-6 October 2005. Annex 9 National Food Systems in Africa—a situation analysis http://www.fao.org/3/a0215e/A0215E24.htm

29. Food and Agriculture Organization (FAO). The state of food insecurity in the world: economic growth is necessary but not sufficient to accelerate reduction of hunger and malnutrition. Rome: Food and agriculture organization of the United Nations (FAO); 2012.

30. Food and Agriculture Organization (FAO, IFAD and WFP). The State of Food Insecurity in the World. Meeting the 2015 international hunger targets: taking stock of uneven progress.

31. Food and Agriculture Organization (FAO). The future of food and agriculture, trends and challenges, Rome; 2017. http://www.fao.org/3/a-i6583 e.pdf. Accessed 29 May 2020

32. Food and Agriculture Organization (FAOSTAT).Food and agriculture data 2018. http://www.fao.org/faostat/en/\#home. Accessed 18 Dec 2020.

33. Food and Agriculture Organization (FAOSTAT). Food and agriculture data 2019. http://www.fao.org/faostat/en/\#home. Accessed 18 Decem 2020

34. Fukuta Y, Konisho K, Senoo-Namai S, Yanagihara S, Tsunematsu H, Fukuo A, Kumashiro T. Genetic characterization of rainfed upland New Rice for Africa (NERICA) varieties. Breed Sci. 2012;62(1):27-37. https://doi. org/10.1270/jsbbs.62.27.

35. Gaffney J, Bing J, Byrne PF, Cassman KG, Ciampitti I, Delmer D, Habben J, Lafitte HR, Lidstrom UE, Porter DO, Sawyer JE, Schussler J, Setter T, Sharp RE, Vyn TJ, Warner D. Science-based intensive agriculture: Sustainability, food security, and the role of technology. Global Food Security. 2019;23:2019.

36. Gakpo OJ, Quainoo R. Study predicts GMO cowpea will boost Ghana's economy. Cornell Alliance for Science; 2018. https://allianceforscience. cornell.edu/blog/2018/12/study-predicts-gmo-cowpea-will-boost-ghana s-economy/. Accessed 23 Jun 2020

37. Garner J, Douglas M, Williams S, Wales WJ, Marett L, Nguyen T, Reich C, Hayes BJ. Genomic selection improves heat tolerance in dairy cattle. Sci Rep. 2016;6:4114. https://doi.org/10.1038/srep34114.

38. Nature Genetics. Genomics and our future food security. Nat Genet. 2019;51:197. https://doi.org/10.1038/s41588-019-0352-8.
39. Goddard ME, Hayes BJ. Genomic selection. J Anim Breed Genet. 2007;124:323-30.

40. Goedde L, Ooko-Ombaka A, Pais G. Private-sector companies can find practical solutions to enter and grow in Africa's agricultural market; 2019. https://www.mckinsey.com/industries/agriculture/our-insights/winni ng-in-africas-agricultural-market0

41. Hendrix C, Brinkman HJ. Food insecurity and conflict dynamics: causal linkages and complex feedback. Stabil Int J Security Dev 2019; 2(2).

42. Higgins J, Moeed A, Eden R. (2018) Video as a mediating artefact of science learning: cogenerated views of what helps students learn from watching video. Asia Pac Sci Educ. 2018;4:6. https://doi.org/10.1186/ s41029-018-0022-7.

43. Hodzic J, Gurbeta L, Omanovic-Miklicanin E, Badnjevic A. Overview of next-generation sequencing platforms used in published draft plant genomes in light of genotypization of immortelle plant (Helichrysium Arenarium). Med Arch (Sarajevo, Bosnia and Herzegovina). 2017;71(4):288-92. https://doi.org/10.5455/medarh.2017.71.288-292.

44. ILRI (International Livestock Research Institute). Reproduction and breeding management. Nairobi, Kenya: ILRl; 2019. https://www.ilri.org/news/ africa's-animal-genetic-resources---wealth-within. Accessed Dec 2019

45. Lambot C. Industrial potential of cowpea. Agriculture raw material, Nestle Research Center, Abidjan, Côte d'loire; 2002. p. 367-75.

46. Langyintuo A, Lowenberg-Deboer S, Faye J, Lambert M, Ibro D, Moussa G, Kergna B, Kushwaha A, Musa S, Ntoukam GS. Cowpea Supply and demand in West and Central Africa. Field Crops Res. 2003:82:215-31.

47. Laurie G, Mallia P, Frenkel DA, Krajewska A, Moniz H, Nordal S, Pitz C, Sandor J. (2010) Managing access to biobanks: how can we reconcile individual privacy and public interests in genetic research? Med Law Int. 2010;10:315-37. https://doi.org/10.1177/096853321001000404.

48. Lescot T, Ganry J. Plantain (Musa spp.) cultivation in Africa: a brief summary of developments over the previous two decades. Acta Horticult. 2010;879:445-55. https://doi.org/10.17660/ActaHortic.2010.879.49.

49. LID. Livestock in poverty-focused development. Livestock in development; 1999

50. Miller CL, Bangsberg DR, Tuller DM, Senkungu J, Kawuma A, Frongillo EA, Weiser SD. Food insecurity and sexual risk in an HIV endemic community in Uganda. AIDS Behav. 2011;15(7):1512-9.

51. Miller JK, Bradford KJ. The regulatory bottleneck for biotech specialty crops. Nat Biotechnol. 2010;28:1012-4.

52. Nassar NMA, Ortiz R. Cassava improvement: challenges and successes. J Agricult Sci. 2007;145:163-71.

53. National Academies of Sciences, Engineering, and Medicine; Division on Earth and Life Studies; Board on Agriculture and Natural Resources; Committee on Genetically Engineered Crops (NASEM). Past Experience and Future Prospects. Genetically Engineered Crops: Experiences and Prospects. Washington (DC): National Academies Press (US); 2016 May 17. 9, Regulation of Current and Future Genetically Engineered Crops. https ://www.ncbi.nlm.nih.gov/books/NBK424533/

54. Nyström ME, Karltun J, Keller C, et al. Collaborative and partnership research for improvement of health and social services: researcher's experiences from 20 projects. Health Res Policy Sys. 2018;16:46. https:// doi.org/10.1186/s12961-018-0322-0.

55. Omamo S, Diao X, Wood S, Chamberlin J, You L, Benin S, Wood-Sichra U, Tatwangire A. Strategic priorities for agricultural development in Eastern and Central Africa. Research Report \# 150. International Food Policy Research Institute; 2006. 2.

56. Onyancha OB, Maluleka JR. Knowledge production through collaborative research in sub-Saharan Africa: How much do countries contribute to each other's knowledge output and citation impact? Scientometrics. 2011:87(2):315-36.

57. Ortiz R, Hartmann P. Beyond crop technology: the challenge for African rural development? Workshop FARA-led CGIAR Challenge Program for Sub-Saharan Africa, 9-15 March 2003, Accra, Ghana Sharing research data to improve public health: full joint statement by funders of health research; 2003.

58. Osei-Amponsah R, Chauhan SS, Leury BJ, Cheng L, Cullen B, Clarke IJ, Dunshea FR. Genetic selection for thermotolerance in ruminants. Animals. 2019;9(11):948. https://doi.org/10.3390/ani9110948.

59. Osei-kyei R, Chan AP. Developing a project success index for public-private partnership projects in developing countries. J Infrastruct Syst. 2017. https://doi.org/10.1061/(ASCE)IS.1943-555X.0000388. 
60. Otte J and Knips V. Livestock development for Sub Saharan Africa. ProPoor Livestock Policy Initiative Res. Report; 2005. p. 1-8.

61. Park JD. Re-inventing Africa's potential. Cham: Springer; 2019. https://doi. org/10.1007/978-3-030-03946-2.

62. Parkes E, Fregene M, Dixon A, Okogbenin E, Boakye-Peprah B, Labuschagne MT. Developing cassava mosaic Disease resistant cassava varieties in Ghana using a marker assisted selection approach. Euphytica. 2015;203:549-56. https://doi.org/10.1007/s10681-014-1262-6.

63. Pohlhaus JR, Cook-Deegan RM. Genomics research: world survey of public funding. BMC Genomics. 2008;9:472. https://doi. org/10.1186/1471-2164-9-472.

64. Pouris A, Ho Y. (2014) Research emphasis and collaboration in Africa. Scientometrics. 2014;98:2169-84. https://doi.org/10.1007/s1119 2-013-1156-8.

65. Ritchie H, Max R. "Energy Production \& Changing Energy Sources." Our World in Data, 28 Mar. 2014, ourworldindata.org/ energy-production-and-changing-energy-sources.

66. Roser M, Ritchie H. Hunger and undernourishment; 2018. https://ourwo rldindata.org/hunger-and-undernourishment. Accessed 29 May 2020.

67. Sachs JD, McArthur JW, Schmidt-Traub G, Kruk M, Bahadur C, Faye M, McCord G. EndingAfrica's poverty trap. In: Brainard WC, Perry GL, editors. Brookings papers on economic activity. Washington: Brookings Institute; 2004. p. 117-240.

68. Sanchez P. Tripling crop yields in tropical Africa. Nat Geosci. 2010;3(5):299-300.

69. Santeramo FG. Food security composite indices: implications for policy and practice. Dev Pract. 2015;25(4):594-600.

70. Sasson A. Food security for Africa: an urgent global challenge. Agricult Food Security. 2012;1(1):1-16.

71. Singh BK, Trivedi P. Microbiome and the future for food and nutrient security. Microbial Biotechnol. 2017;10:50-3.

72. Singh BK, Trivedi P, Egidi E, Macdonald CA, Delgado-Baquerizo M. Crop microbiome and sustainable agriculture. Nat Rev Microbiol. 2020;18:6012. https://doi.org/10.1038/s41579-020-00446-y.

73. Southwood D, Ranganathan S. Genome databases and browsers. Encycl Bioinform Comput Biol. 2019;2:251-6.

74. Stephens ZD, Lee SY, Faghri F, Campbell RH, Zhai C, Efron MJ, Ravishankar I, Schatz CM, Sinha S, Robinson GE. Big data: astronomical or genomical? PLoS Biol. 2015;13(7):e1002195. https://doi.org/10.1371/journ al.pbio.1002195.
75. Tamminen S. Changing values of farm animal genomic resources from historical breeds to the Nagoya Protocol. Front Genet. 2015;6:279. https:// doi.org/10.3389/fgene.2015.00279.

76. The Nagoya Protocol. 2014. https://www.cbd.int/abs/about/default.shtml /. Accessed 26 Aug 2020

77. The Wellcome Trust. Sharing data from large-scale biological research projects: a system of tripartite responsibility. http://www.genome.gov/ Pages/Research/WellcomeReport0303.pdf.Google Scholar

78. United Nations General Assembly (UN). Transforming our world: The 2030 agenda for sustainable development. New York: United Nations General Assembly; 2015.

79. United Nations Department of Economic and Social Affairs (UN). "World population prospects 2019, population data, file: total population-both sexes, estimates tab". United Nations Population Division; 2019. Accessed 23 June 2020

80. Wagner CS, Brahmakulam I, Jackson B, Wong A, Yoda T. Science and technology collaboration: building capacities in developing countries. Santa Monica, CA: RAND; 2001.

81. Wagner CS, Park HW, Leydesdorff L. The continuing growth of global cooperation networks in research: a conundrum for national governments. PLoS ONE. 2015;10:e0131816. https://doi.org/10.1371/journ al.pone.0131816.

82. Wang W, Cao XH, Miclăuș M, Xiong W and Xu J-H, . The promise of agriculture genomics. Int J Genomics. 2017;2017:1-3.

83. Weimer BC. 100K Pathogen genome project. Genome Announc 2007; 5: e00594-17 (2017).

84. Zhan YA, Wray CG, Namburi S, Glantz ST, Laubenbacher R, Chuang JH. Fostering bioinformatics education through skill development of professors: big genomic data skills training for professors. PLoS Comput Biol. 2019;15(6):e1007026. https://doi.org/10.1371/journal.pcbi.1007026.

\section{Publisher's Note}

Springer Nature remains neutral with regard to jurisdictional claims in published maps and institutional affiliations.
Ready to submit your research? Choose BMC and benefit from:

- fast, convenient online submission

- thorough peer review by experienced researchers in your field

- rapid publication on acceptance

- support for research data, including large and complex data types

- gold Open Access which fosters wider collaboration and increased citations

- maximum visibility for your research: over 100M website views per year

At BMC, research is always in progress.

Learn more biomedcentral.com/submissions 